Article

\title{
Carbon Emissions Reduction and Corporate Financial Performance: The Influence of Country-Level Characteristics
}

\author{
Robin van Emous ${ }^{1}$, Rytis Krušinskas ${ }^{2}$ and Wim Westerman ${ }^{1, *(D)}$ \\ 1 Department of Economics, Econometrics and Finance, Faculty of Economics and Business, \\ University of Groningen, 9747 AE Groningen, The Netherlands; robinvanemous@gmail.com \\ 2 School of Economics and Business, Kaunas University of Technology, LT-44029 Kaunas, Lithuania; \\ rytis.krusinskas@ktu.lt \\ * Correspondence: w.westerman@rug.nl
}

Citation: van Emous, R.; Krušinskas, R.; Westerman, W. Carbon Emissions Reduction and Corporate Financial Performance: The Influence of Country-Level Characteristics. Energies 2021, 14, 6029. https:// doi.org/10.3390/en14196029

Academic Editors: Philipp Bagus and José Antonio Peña-Ramos

Received: 28 July 2021

Accepted: 18 September 2021

Published: 22 September 2021

Publisher's Note: MDPI stays neutral with regard to jurisdictional claims in published maps and institutional affiliations.

Copyright: (c) 2021 by the authors. Licensee MDPI, Basel, Switzerland. This article is an open access article distributed under the terms and conditions of the Creative Commons Attribution (CC BY) license (https:// creativecommons.org/licenses/by/ $4.0 /)$.

\begin{abstract}
Using a cross-country dataset covering 9265 observations on 1785 firms representing 53 countries over the period 2004-2019, this study investigates the relation between carbon emissions reduction and corporate financial performance (CFP). We perform OLS regressions with fixed effects. We found that carbon emissions reduction increases the return on assets, the return on equity, and the return on sales, whereas it has no effect on the Tobin's $Q$ and the current ratio. The positive relationship with the return on assets is stronger for firms with a higher responsibility score. We study country characteristics by modeling GDP growth, overall emissions within a country, and the presence of carbon emissions legislation. Our results indicate that the overall carbon emissions of a country and the presence of carbon emissions legislation are related to both corporate carbon emissions reduction and CFP. Moderating effects of the country's overall emissions and the presence of carbon emissions legislation do not affect the relationship between carbon emissions reduction and CFP. Despite the further understanding gained, the issue of whether it "pays to be green" can still not be resolved well.
\end{abstract}

Keywords: carbon emissions reduction; corporate financial performance; country-level characteristics

\section{Introduction}

Climate change is one of the most threatening and complex challenges the world has ever faced [1]. The main cause of climate change is carbon emissions that are released into the air [2]. The challenge of climate change is gaining ever more attention. Countries and organizations they constitute, such as the United Nations and the European Union, are all around the world aiming to reduce overall carbon emissions. For instance, carbon emissions reduction is one of the United Nations Sustainable development goals to reduce the amount of greenhouse gasses by $45 \%$ by 2030 [3]. The European Union aims to reduce greenhouse emissions by $55 \%$ by 2030 [4]. These goals show the importance of the reduction of the overall greenhouse gasses emission worldwide. Legislators attempt to encourage or enforce firms to reduce their overall emissions, but it is unclear how firms respond to this threat of climate change.

Moreover, existing studies still leave the debate open about whether it pays to be green. On the one side [5], they claim that more polluting firms have a better corporate financial performance (hereafter: CFP). The main argument is that being or becoming green requires investments and it is not certain that these will be earned back. Delmas et al. [6] show that becoming green reduces the short-term profitability of firms but pays off in the long term. This short-term decrease in profitability may affect the decisions making of managers due to short-term performance targets. In addition, these arguments can provide an answer to the issue of why firms respond to the climate change issue slowly [7]. On the other hand, researchers have found that firms with lower emissions have a better CFP compared to more polluting firms [8]. Fujii et al. [9] show that firms with lower emissions had better 
profitability and a higher capital turnover. Fernández-Cuesta et al. [10] found that firms with a better carbon performance were able to obtain more long-term financial debt to finance their environmental investments. Gallego-Alvarez et al. [11] found that during times of economic crisis, the synergy between environmental and financial performance is higher, indicating that firms must invest in sustainable projects to enhance their relationship with stakeholders even during crisis times.

Our study contributes by exploring the effect of carbon emissions reduction on the financial performance of firms by using the following financial performance indicators: return on assets (hereafter: ROA), return on equity (hereafter: ROE), return on sales (hereafter: ROS), Tobin's $Q$, and (as a new element) the current ratio (hereafter: $C R$ ). Gallego-Alvarez et al. [12] suggest that future research into the relationship between CFP and carbon emissions reduction should include the effect of country characteristics in a large cross-country sample. Their suggestion formed the foundation for this research. This study will look at an extraordinarily large cross-country sample including 1785 firms covering 53 countries over the period 2004-2019, by using financial and environmental firm-level data from the Thomson Reuters Eikon Database. Moreover, we investigate the effect of overall carbon emissions, economic development, and the presence of carbon emissions legislation within the home country of a firm, by using country-level data from the World Bank Database. We test this by including countries' overall emissions and a dummy that indicates the presence of carbon emissions legislation within a country as a moderating variable. The inclusion of the effect of carbon emissions legislation connects to a suggestion made by Lewandowski [7] that future research should focus on the incentives firms have to reduce their emissions. We control for overall growth in GDP by including this country characteristic as well [13].

\section{Literature Review and Hypotheses Development}

This section covers the existing literature used to provide background for this study. The first part focuses on the relationship between carbon emissions reduction and CFP; the second part includes the moderating effect of country characteristics on the relationship between carbon emissions reduction and CFP, and the third part includes the firm's level of responsibility as moderating effect on the relationship between carbon emissions reduction and CFP.

\subsection{Carbon Emissions Reduction and CFP}

The relation between carbon emissions and CFP has been studied before. Busch et al. [5] found that more polluting firms performed better financially compared to firms with lower emissions. However, Busch and Lewandowski [14] found evidence that firms with lower emissions performed better financially. In addition, studies on the relation between carbon mitigation and CFP also showed mixed results. Gallego-Alvarez et al. [12] found that carbon emissions reduction improves the CFP in terms of return on equity and return on assets. Lewandowski [7] found that carbon emissions reduction leads to an increase in the return on sales but a decrease in CFP measured by Tobin's Q. Kim et al. [15] showed that carbon mitigation reduces the costs of capital, this reduction can be used to overcome costs that come along with emission reduction. Delmas et al. [6] found that the short-term profitability of firms is affected by carbon emissions reduction, but also showed that Tobin's Q improves due to the emission reduction, suggesting that investors see the potential longterm value of the mitigation of the emissions. The goal of this study is to understand the relation between carbon emissions reduction and CFP and to assess the effect of country characteristics on this relationship, as suggested by Gallego-Alvarez et al. [12]. The main research question can be stated briefly as follows: "Does carbon emissions reduction impact the CFP of firms?".

In addition, the measurement of CFP differs among the different studies. Lewandowski [7] uses the ROA, ROE, ROS, ROIC, and Tobin's Q. Delmas et al. [6] use the ROA and Tobin's Q. Gallego-Alvarez et al. [12] use the ROA and the ROE. Most of the researchers, therefore, 
mainly focus on accounting profitability measures. To cover the effect of the market value of firms, the Tobin's $Q$ is included since the Tobin's $Q$ ratio reflects the expectations of the stock market on the future profitability and growth of firms [16]. Based on the mixed results, we formulate the main hypothesis without direction, as follows:

Hypothesis 1 (H1). Carbon emissions reduction influences the CFP of firms.

\subsection{Carbon Emissions Reduction, CFP, and Country Characteristics}

We investigate the effect of two country characteristics. First, we look at the effect of the overall carbon emissions of a country to see whether the effect of carbon emissions reduction is different within more polluting countries. Alonso-Martinez et al. [17] found that the overall carbon emissions of a country are related to the environmental, social, and governance (ESG) responsibility of firms. They suggest that higher levels of pollution raise the awareness towards environmental sustainability within a country. Jiménez-Parra et al. [18] claim that the concerns around air pollution lead to greater environmental demands by stakeholders. The second hypothesis deals with pollution within a country and reads as follows:

Hypothesis 2 (H2). The relationship between carbon emissions reduction and CFP is influenced by the overall carbon emissions within a country.

Firms have multiple incentives to reduce their overall emissions, which are driven by the pressures of different stakeholders thriving on the importance of climate awareness [19]. The main stakeholder used in this study is the legal authorities that implement regulations to achieve overall greenhouse gasses reductions. These days, more and more major organizations such as the United Nations, the European Union, and a wide variety of countries set climate goals to reduce their overall emissions. To achieve these goals, they introduced multiple market-based mechanisms that can be distinguished into two groups: quantity control and price control [20]. Cap and trade emissions trading schemes are the most important as to quantity control, with 27 trading schemes being implemented worldwide [21]. In a cap and trade system, companies with higher carbon emissions have to lower their emissions or have to buy additional allowances, whereas companies with a lower level of emissions are able to sell their surplus of allowances [22]. The price control mechanism focuses on the taxation of carbon emissions. Both systems are implemented in a wide variety of countries. A meta-analysis by Galama and Scholtens [8] indicates that the positive relationship between CFP and CEP is higher for countries that have more stringent carbon regulations. New to the existing body of work is that we include the presence of a market-based mechanism within a country as a moderating variable.

The impact of cap and trade systems on CFP has been previously researched; however, the results are mixed. Brouwers et al. [23] found that only firms that are not able to pass their costs to their customers are negatively impacted. Griffin [24] shows that the net income of Californian firms was negatively impacted by the AB32, the Californian cap, and trade system. Moreover, Delmas et al. [6] found that the short-term profitability of firms is negatively impacted by carbon emissions reduction, which is the main goal of these programs. Marin et al. [25] show that the EU Emission Trading Scheme (henceforth: EU ETS) has a positive impact on the turnover, investment intensity, and labor productivity of firms. De Giovanni and Vinzi [26] found no relationship between the impact of the EU ETS and CFP. Jong et al. [27] show that shareholders regard the EU ETS as value-relevant, which is in line with the positive relation Delmas et al. [6] found between Tobin's Q and carbon emissions reduction. Taxation is the most important quality control mechanism, being fully implemented in 25 countries. Luo and Tang [28] researched the impact of the implementation of carbon tax and concluded that shareholders value is negatively associated with the implementation of carbon tax regulations, which can be caused by an increase in competition of firms in countries without carbon taxation [29]. Their results also 
show that the carbon emissions of the firms within their sample were negatively correlated to their abnormal returns.

To examine the effect of regulatory forces to enforce carbon emissions reduction, the third hypothesis focuses on the effects of carbon emissions legislation within a country. Galama and Scholtens [8] indicate that the positive relation between CFP and CEP is stronger in countries with more stringent climate policies. To investigate whether such a claim stands, we include a variable measuring the presence of carbon emissions legislation. Moreover, we look into two different mechanisms: carbon emissions trading schemes and carbon taxation.

Hypothesis 3 (H3). The relationship between carbon emissions reduction and CFP is influenced by the presence of carbon taxation or emission trading schemes within a country.

\subsection{Carbon Emissions Reduction, CFP, and Responsibility}

Russo and Fouts [30] argue that firms that act responsibly to reduce their environmental footprint can create a competitive advantage. Beck et al. [31] argue that firms that engage more in responsible activities have a better CFP. Sariannidis et al. [32] researched the effect of carbon emissions on the CFP of responsible firms. Their main finding is that responsible firms react negatively to a global increase in overall emissions. Jiménez-Parra et al. [18] found that the presence of more responsible firms reduces the overall emissions within a country. To investigate whether the relation between carbon emissions reduction and CFP is different for responsible firms, we create the fourth hypothesis:

Hypothesis 4 (H4). The relationship between carbon emissions reduction and CFP is influenced by a firm's level of responsibility.

\section{Results}

\subsection{Data}

The existing body of work [5-7,12] provides insights into carbon emissions reduction effects; however, these studies contain limitations. Their first main limitation refers to the relatively small sample size and period. Gallego-Alvarez [12] only used 257 observations. Delmas et al. [6] have 1095 (ROA) and 880 observations (Tobin's Q). Busch et al. [5] expand these amounts to 2884 and 2896, respectively. Our study overcomes this limitation by extending the sample period to 2000-2020 and using a large cross-country sample of 9265 observations.

Another limitation of the existing literature is endogeneity. To encounter this limitation, we will follow the methodology of Busch et al. [5] and lag the dependent variable. In addition, we include country characteristics and multiple control variables to reduce the threat of endogeneity. Lewandowski [7] points out that the carbon intensity of firms might be correlated to the CFP indicators. Delmas et al. [6] also describe the limitation of the current measuring methods. To address this issue, we will not only include profitability ratios, but also solvency and liquidity ratios.

The existing research uses multiple databases to measure the carbon emissions of the companies. Delmas et al. [6] describe the quality of their emission data as a limitation, since they use data from Trucost that also contains estimated emissions. They suggest future research only uses the reported carbon emissions. We follow Lewandowski [7] by using the ASSET4 Database. The carbon emission data can be separated into three scopes: scope 1 covers all the direct emissions from production processes on-site, scope 2 covers all indirect emissions from the usage of purchased energy, and scope 3 includes all other emission sources [6,32]. This research will follow Lewandowski [7] by only including the sum of the emission data for scope 1 and scope 2. Lewandowski argues that the quality of the data for scope 3 is not very high and the carbon emissions within scope 3 are not impacted by regulations and, therefore, are not a significant cost driver. 
This research uses a large global sample covering 53 countries. The observations are gathered over the period 2004-2019. The final sample contains 9265 observations covering 1785 firms. The financial and carbon emission data is drawn from the Thomson Reuters Eikon Database. This database contains data for 50,000 active firms covering 125 markets [33]. The emission data is part of the ASSET4 Database, which contains large amounts of responsibility data. The country-level data is gathered from the World Bank Database. Observations with negative sales and assets are eliminated. The two types of data are merged and winsorized at the 1 and 99 percent levels to eliminate outlier effects. In finance research, it is common that financial firms are excluded. Lewandowski [7] and Delmas et al. [6] argue that financial firms have low values for the ROA and carbon emissions though. A robustness check shows that the presence of financial firms does not affect the results.

\subsection{Variables}

Appendix A provides an overview of the variables that are used within this research. The independent variable used in this research is DELTACO2, which represents the change in carbon intensity over a year. It is calculated as the annual change in emissions scaled by the annual net sales to account for changes caused by changes in the scale of operations. The enlargement or reduction of company operations the total carbon emissions are divided by the total sales within year $t$. To reduce the effect of endogeneity, the independent variable DELTACO2 is lagged with $t-1$. Existing literature $[7,34]$ uses the squared of the variation in carbon intensity to account for a curvilinear relationship between carbon performance and CFP. We name it DELTACO2^2.

The dependent variable within this study is CFP, which represents the corporate CFP of firms. In this research, we use multiple variables that measure the CFP: ROA, ROS, ROE, and Tobin's Q. In addition to the existing literature, we also include the current ratio, which measures the firm's ability to repay short-term debts [35]. This research uses multiple profitability ratios to measure the CFP. To reduce the impact of multicollinearity, we follow the methodology of Gallego-Alvarez et al. [12]. They calculate the return on assets with the usage of the operating income instead of the net income, which is already used in the return on sales and return on equity. Because of the availability and quality of the actual data, we follow the method by Chung and Pruitt [36] to calculate Tobin's Q. It is the sum of the market capitalization, current liabilities net of the current assets, and the book value of the long-term debts divided by the total assets of a firm. Next to the profitability and stock market performance indicators, we include a liquidity ratio. The current ratio, $C R$, reflects the firm's ability to repay short-term liabilities. Durrah et al. [35] argue that the firm's liquidity influences the CFP, since liquidity problems can affect the firm's level of operations and a higher level of liquidity can benefit the firm's level of operations due to more available funds for, e.g., investments. $C R$ is calculated by dividing the current assets by the current liabilities.

This research includes several moderating variables. The first moderating variable is CO2EMISSION, which measures the average overall carbon emissions of the home country of the firm as a ratio of a country's overall GDP. We took the average value over the last 20 years. We also compute the variable $L E G A L$, which represents a dummy variable that indicates the presence or participation in a trading emission scheme or carbon taxation program in a certain country or year. An overview of the presence of carbon emissions legislation by country is provided in Appendix $\mathrm{B}$. The variable LEGAL provides insight into the reasoning of firms to reduce their emissions, whether this is forced by regulations or carried out voluntarily. We also compute the variable ESG that measures the responsibility level of a firm.

To reduce the impact of omitted variable bias, we compute a wide variety of firm and county-level control variables. The first variable we control for is SIZE, by using the logarithm of the total market capitalization. The second control variable is LEVERAGE, measured by dividing the long-term debts by the total assets. The third variable we control 
for is CAPINT, which represents the capital intensity of firms. It is calculated by dividing the total equity by the total sales. The fourth control variable is DELTASALES, which represents the ratio of the differences in sales between year $\mathrm{t}$ and year $\mathrm{t}-1$. The fifth control variable, CASHFLOW, represents the firm's free cash flow at the end of year $t$. It is presented as a ratio of the annual sales of the firm. Finally, we control for the economic development of the country where the firm is registered. The variable GDPGROWTH represents the annual growth in GDP compared to year $t-1$. The GDP is defined as the sum of all gross value added by producers plus product taxes and minus any subsidies that are not yet included.

\subsection{Methodology}

We use OLS regression to estimate the effect of carbon emissions reduction on CFP and to test the main and alternative hypotheses. We include year, country, and industry fixed effects to control for differences caused by unobserved time-invariant characteristics. We cluster all the standard errors on the firm level. To reduce the effect of endogeneity, the main independent variable DELTACO 2 and the variable DELTACO2^ 2 are lagged with $\mathrm{t}-1$ throughout all the models. CFP represents the financial performance of firm $\mathrm{i}$ in year $\mathrm{t}$, and is measured by ROA, ROE, ROS, TOBIN, and CR.

The first model tests for the relation between carbon emissions reduction and CFP. The regression function used is the following:

$$
\begin{aligned}
\text { CFP }_{\mathrm{i}, \mathrm{t}}=\beta_{0}+ & \beta_{1} \text { DELTACO }_{\mathrm{i}, \mathrm{t}-1}+\beta_{2} \text { DELTACO2^}^{\wedge} 2_{\mathrm{i}, \mathrm{t}-1}+\beta_{3} \text { CONTROL VARIABLES } \\
& + \text { fixed effects }_{\mathrm{i}, \mathrm{c}, \mathrm{t} . \mathrm{u}}+\varepsilon_{\mathrm{t}} \mathrm{CFP}_{\mathrm{i}, \mathrm{t}} \\
& =\beta_{0}+\beta_{1} \text { DELTACO } 2_{\mathrm{i}, \mathrm{t}-1}+\beta_{2} \text { DELTACO }^{\wedge} 2_{\mathrm{i}, \mathrm{t}-1} \\
& +\beta_{3} \text { CONTROL VARIABLES }+ \text { fixed effects }_{\mathrm{i}, \mathrm{c}, \mathrm{t} \text {. } \mathrm{u}}+\varepsilon_{\mathrm{t}}
\end{aligned}
$$

Model 2 introduces the three moderating variables to test the alternative hypotheses: CO2EMISSION, LEGAL, and ESG. We employ the following regression equation:

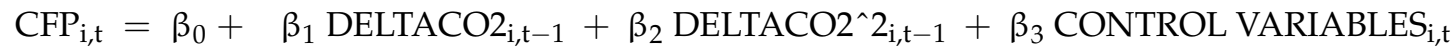

$$
\begin{aligned}
& +\beta_{4} C_{-} C O 2_{i, t}+\beta_{4} \text { LEGAL }_{i, t}+\beta_{4} \text { ESG }_{i, t}+\text { fixed effects }_{i, c, t . u}+\varepsilon_{t} \text { CFP }_{i, t} \\
& =\beta_{0}+\beta_{1} \text { DELTACO }_{\mathrm{i}, \mathrm{t}-1}+\beta_{2} \text { DELTACO }^{\wedge} 2_{\mathrm{i}, \mathrm{t}-1} \\
& +\beta_{3} \text { CONTROL VARIABLES }_{i, \mathrm{t}}+\beta_{4} \mathrm{C}_{-} \mathrm{CO} 2_{\mathrm{i}, \mathrm{t}}+\beta_{4} \text { LEGAL }_{\mathrm{i}, \mathrm{t}}+\beta_{4} \mathrm{ESG}_{\mathrm{i}, \mathrm{t}} \\
& + \text { fixed effects } \mathrm{i}_{\mathrm{i}, \mathrm{c}, \mathrm{t.u}}+\varepsilon_{\mathrm{t}}
\end{aligned}
$$

Model 3 tests include three interaction variables to measure the effect of a certain variable on the relation between carbon emissions reduction and CFP. The first of these is DELTACO2 X CO2, which measures the effect of the overall emissions in the country where firm $i$ is registered. The second interaction variable is DELTACO2 X LEGAL, which indicates the effect of the presence of carbon emissions legislation in the country where firm $\mathrm{i}$ is registered. The third interaction variable, DELTACO2 X ESG, measures the effect of the company's responsibility score on the relation between carbon mitigation and CFP. We use the following regression equation:

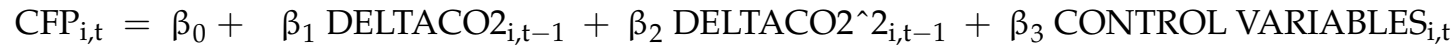

$$
\begin{aligned}
& +\beta_{4} \text { DELTACO } 2 \times C O 2_{c, t}+\beta_{5}{\text { DELTACO } 2 \times \text { LEGAL }_{c, t}} \\
& +\beta_{6} \text { DELTACO2 X ESG }_{i, t}+\text { fixed effects }_{i, c, t . u}+\varepsilon_{t} \text { CFP }_{i, t} \\
& =\beta_{0}+\beta_{1} \text { DELTACO }_{\mathrm{i}, \mathrm{t}-1}+\beta_{2} \text { DELTACO2^ }^{\wedge} 2_{\mathrm{i}, \mathrm{t}-1}
\end{aligned}
$$

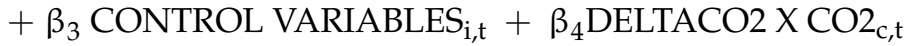

$$
\begin{aligned}
& +\beta_{5} \text { DELTACO2 X LEGAL }_{c, t}+\beta_{6} \text { DELTACO2 X ESG }_{i, t}+\text { fixed effects } s_{i, c, t . u} \\
& +\varepsilon_{\mathrm{t}}
\end{aligned}
$$

\section{Results}

\subsection{Descriptive Statistics}

Table 1 provides descriptive statistics for the sample covering 9265 observations. The mean value for DELTACO2 states that the firms within the sample are overall reducing 
their emissions. The negative median value for this coefficient tells that over $50 \%$ of the observations contain a negative value, which means that firms are reducing their overall emissions compared to their sales. The positive mean and median values for $R O A, R O E$, and ROS show that the firms within the sample are overall profitable during the period 2004-2019. The mean value for the coefficient TOBIN of 1.314 shows that on average the market value of the firms within the sample is higher than the book value of their assets. The mean value of the variable CO2EMISSION is 0.312 . Countries on average emit $0.312 \mathrm{~kg}$ $\mathrm{CO}_{2}$ per unit of GDP. The lower median value of 0.285 and the maximum value of 0.849 shows that the average emissions are driven by some specific countries. The mean value for the variable $L E G A L$ of 0.752 indicates that on average $75.2 \%$ of the observations represent a firm that is registered in a country with carbon emissions legislation. The variable ESG measures the firm's level of responsibility on a scale from 1 to 100 . The mean value of the sample is 55.619 and the median value is 55.847 suggesting that the data for this variable is symmetrically distributed.

Table 1. Descriptive statistics.

\begin{tabular}{|c|c|c|c|c|c|c|}
\hline Variable & $\mathbf{N}$ & Mean & Median & STD & Min & Max \\
\hline DELTACO2 & 9265 & -0.00000770 & -0.00000006 & 0.00010950 & -0.00063240 & 0.00050330 \\
\hline DELTACO2^2 & 9265 & 0.00000002 & 0.00000001 & 0.00000014 & 0.00000000 & 0.00000127 \\
\hline$R O A$ & 9265 & 0.068 & 0.065 & 0.075 & -0.238 & 0.285 \\
\hline$R O E$ & 9265 & 0.099 & 0.057 & 0.347 & -0.705 & 2.936 \\
\hline ROS & 9265 & 0.108 & 0.109 & 0.322 & -1.636 & 1.623 \\
\hline TOBIN & 9265 & 1.314 & 0.897 & 1.485 & -0.091 & 10.333 \\
\hline$C R$ & 9265 & 1.554 & 1.344 & 0.863 & 0.400 & 5.257 \\
\hline$S I Z E$ & 9265 & 23.805 & 23.491 & 2.492 & 18.123 & 29.975 \\
\hline LEVERAGE & 9265 & 0.197 & 0.180 & 0.131 & 0.000 & 0.577 \\
\hline CAPINT & 9265 & 2.537 & 1.366 & 6.478 & 0.344 & 59.448 \\
\hline DELTASALES & 9265 & 0.049 & 0.035 & 0.163 & -0.425 & 0.783 \\
\hline CASHFLOW & 9265 & 0.209 & 0.114 & 0.610 & -0.381 & 5.560 \\
\hline GDPGROWTH & 9265 & 0.017 & 0.019 & 0.020 & -0.091 & 0.252 \\
\hline CO2EMISSION & 9265 & 0.312 & 0.285 & 0.151 & 0.109 & 0.849 \\
\hline$L E G A L$ & 9265 & 0.752 & 1.000 & 0.432 & 0.000 & 1.000 \\
\hline$E S G$ & 9265 & 55.619 & 55.847 & 15.344 & 19.753 & 87.065 \\
\hline
\end{tabular}

Descriptive statistics for the entire sample, covering 9265 observations representing 53 countries. The independent variables are DELTACO2 and DELTACO2^2, which are both lagged with $\mathrm{t}-1$. The dependent variables are ROA, ROE, ROS, TOBIN, and $C R$. The control variables are SIZE, LEVERAGE, CAPINT, DELTASALES, CASHFLOW, and GDPGROWTH. The moderating variables covering the alternative hypotheses are CO2EMISSION, LEGAL, and ESG. The firm-level data is collected from the Thomson Reuters Eikon Database and the country-level data is obtained with the usage of the World Bank Database. The sample covers observations over the period 2004-2019. All firm-level data is winsorized at the 1 and 99 percentile.

\subsection{Pearson Correlation Matrix}

Table 2 provides the Pearson correlation matrix. Values above 0.8 are considered as a strong correlation. The results provided in Table 2 show two correlations above the threshold of 0.8. The first strong correlation is between the variables ROS and CASHFLOW, with a value of 0.878 , the second strong correlation is between the variables CAPINT and CASHFLOW with a value of 0.928 . To see whether this high correlation causes multicollinearity, we conduct a variance inflation factor (hereafter: VIF) analysis on our regression models. For this test, we look at the regression model that includes the moderating variables but does not include the interaction variables. There is no single VIF value above 10, which is regarded as a rule of thumb hurdle on multicollinearity. 
Table 2. Pearson correlation matrix.

\begin{tabular}{|c|c|c|c|c|c|c|c|c|c|c|c|c|c|c|c|}
\hline & (1) & (2) & (3) & (4) & (5) & (6) & (7) & (8) & (9) & (10) & (11) & (12) & (13) & (14) & (15) \\
\hline (1) DELTACO2 & 1 & & & & & & & & & & & & & & \\
\hline (2) $R O A$ & -0.053 & 1 & & & & & & & & & & & & & \\
\hline (3) $R O E$ & -0.016 & 0.528 & 1 & & & & & & & & & & & & \\
\hline (4) $\mathrm{ROS}$ & -0.006 & 0.355 & 0.229 & 1 & & & & & & & & & & & \\
\hline (5) TOBIN & -0.023 & 0.369 & 0.185 & 0.162 & 1 & & & & & & & & & & \\
\hline (6) $C R$ & 0.005 & 0.123 & -0.007 & 0.027 & 0.057 & 1 & & & & & & & & & \\
\hline (7) $S I Z E$ & 0.016 & 0.163 & 0.095 & 0.180 & 0.139 & 0.036 & 1 & & & & & & & & \\
\hline (8) LEVERAGE & 0.002 & -0.039 & 0.037 & -0.040 & 0.076 & -0.183 & -0.161 & 1 & & & & & & & \\
\hline (10) DELTASALES & -0.016 & 0.240 & 0.113 & 0.162 & 0.093 & 0.034 & 0.068 & -0.027 & 0.068 & 1 & & & & & \\
\hline (11) CASHFLOW & 0.021 & 0.198 & 0.103 & 0.878 & 0.117 & -0.005 & 0.139 & 0.006 & 0.928 & 0.116 & 1 & & & & \\
\hline (12) GDPGROWTH & 0.029 & 0.061 & 0.043 & 0.193 & 0.113 & 0.016 & 0.022 & 0.020 & 0.214 & 0.047 & 0.222 & 1 & & & \\
\hline (13) CO2EMISSION & -0.027 & 0.002 & -0.021 & 0.033 & 0.028 & 0.070 & 0.003 & -0.009 & 0.040 & 0.047 & 0.039 & 0.130 & 1 & & \\
\hline (14) LEGAL & 0.020 & 0.014 & 0.026 & -0.128 & -0.021 & -0.026 & -0.216 & 0.083 & -0.154 & -0.074 & -0.150 & -0.144 & -0.351 & 1 & \\
\hline (15) ESG & -0.009 & 0.104 & 0.067 & 0.064 & 0.083 & -0.068 & 0.155 & 0.041 & 0.029 & -0.011 & 0.049 & -0.014 & -0.086 & 0.049 & 1 \\
\hline
\end{tabular}

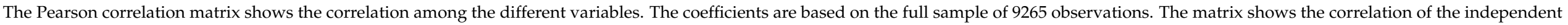

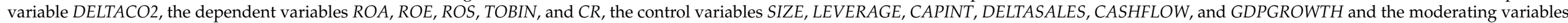
CO2EMISSION, LEGAL, and ESG. The variable definitions can be found in Table A1. 


\subsection{Regression Analysis ROA, ROE, and ROS}

We now provide the results of the OLS regression on the relation between carbon emissions reduction and CFP as denoted by three variables: ROA, ROE, and ROS. Table 3 provides three different models. Model 1 only contains the dependent variable and the control variables, Model 2 introduces the moderating variables, and Model 3 introduces the created interaction variables for these moderating effects. The first dependent variable to measure CFP is $R O A$, which represents the return on assets. The regression results can be found in Models 1-3 of Table 3. Looking at the coefficient of DELTACO2 throughout Models 1-2, the results show a strong significant negative relation between CFP and carbon emissions reduction $(\beta 1=-31.7559, \beta 2=-31.8168, p=<0.01)$. The reduction in carbon emissions relates positively to a firm's return on assets. The value shown in the first Model $(\beta 1=-31.7559)$ shows that if a firm reduces its greenhouse emissions by $100 \%$, its return on assets increases by $31.76 \%$ ceteris paribus. In Model 3, the coefficient remains negative but at a higher confidence interval $(\beta 2=-66.2760, p=<0.1)$. These findings are in line with Gallego-Alvarez et al. [12] who found a similar relation but which contradicts Delmas et al. [6] who found a negative relation between carbon emissions reduction and short-term profitability. The variable DELTACO2^2 shows negative but insignificant coefficients. These findings do not show a curvilinear relation between CFP in terms of return on assets and carbon emissions reduction. This contradicts the results of Lewandowski [7], who found evidence for a curvilinear relation between ROA and carbon mitigation.

The country-level control variable within Models 1-3, GDPGROWTH, measures the economic development of a country where firm i is headquartered. The coefficient for this variable in Models 1 and 2 is positive but insignificant and in Model 3 the sign of the coefficient changes. The lack of significant results suggests that economic development does not influence a firm's profitability within this sample. Model 2 in Table 3 introduces the moderating variables ESG, CO2EMISSION, and LEGAL as control variables. The positive but insignificant coefficient $(\beta 2=0.0019, p=>0.1)$ suggests that the overall carbon emissions of a country do not influence the profitability of companies. The coefficient for the variable ESG is positive and significant $(\beta 2=0.0002, p=<0.01)$, which indicates that more responsible firms tend to have a higher return on assets. The results for the variable $L E G A L$ are positive but insignificant $(\beta 2=0.0011, p=>0.1)$, suggesting that the presence of carbon emissions legislation within a country does not influence the overall profitability of firms. Model 3 introduces the interaction variables that measure the effect of a certain variable on the relation between CFP and carbon emissions reduction. The positive significant coefficient for the variable DELTACO2 X ESG $(\beta 3=0.8079, p=<0.1)$ indicates that the positive relation between carbon emissions reduction and return on assets is higher for firms with a higher ESG score. For the other moderating variables DELTACO2 $X \operatorname{LEGAL}(\beta 3=10.4208, p=>0.1)$ and DELTACO2 X CO2 $(\beta 3=-56.6007, p=>0.1)$, the results are insignificant, which suggests that the presence of carbon emission legislation and a country's overall emissions do not influence the relation between carbon emissions reduction and CFP.

The second profitability measurement for CFP within this research is ROE which represents the firm's return on equity and is calculated by dividing the net income by the equity for firm $i$ in year $t$. The results for the performed OLS regression on the dependent variable $R O E$ are presented in Table 3 under Models 4-6. For the variable DELTACO2, Models 4 and 5 show a negative significant relationship between carbon mitigation and $\operatorname{ROE}(\beta 4=-67.2307, \beta 5=-67.1948, p=<0.05)$, suggesting that firms that reduce their emissions had an overall better return on equity. The results in Model 6 provides a negative but insignificant relation $(\beta 6=-116.407, p=>0.1)$. For the variable DELTACO2 2 , the results in Models 4-6 provide negative and significant coefficients $(\beta 4=-59,500, \beta 5=-59,500, \beta 6=-59,100, p=<0.05)$, which provides evidence for the curvilinear relation between carbon emissions reduction and CFP, which was also found in the results of Lewandowski [7]. For the control variables SIZE, DELTASALES, and 
CASHFLOW, the coefficients in Models 4-6 are all positive and significant. For the variable DELTASALES, the models show positive and significant results. The coefficients for the variable CAPINT results are negative and significant $(\beta 4=-0.0279, \beta 5=-0.0278, \beta 6=$ $-0.0278, p=<0.01$ ), indicating that firms that are more capital intensive are less profitable. The coefficients for the variable GDPGROWTH are negative but insignificant, indicating that the economic growth of the country in which a firm is registered does not influence ROS. Model 5 introduces the moderating variables as control variables. The positive and significant results for the variable CO2EMISSION ( $\beta 5=0.1755, \beta 5=0.1762, p=<0.05)$ show that companies in more polluting countries have a higher ROE. For the variable $E S G$, the coefficients in Models 5 and 6 are positive and significant $(\beta 5=0.0006, \beta 5=0.0006$, $p=<0.1)$. The results for the variable $L E G A L$ are insignificant. Model 6 introduces the interaction variables to see whether these variables influence the relation between carbon emissions reduction and ROE. The coefficients for the variables DELTACO2 X ESG, DELTACO2 X LEGAL, and DELTACO2 X CO2 are all positive but insignificant, providing no evidence for a moderating effect.

Table 3. Regression analysis on ROA and ROE.

\begin{tabular}{|c|c|c|c|c|c|c|}
\hline CFP Measure & ROA & ROA & ROA & ROE & ROE & ROE \\
\hline Variable & Model 1 & Model 2 & Model 3 & Model 4 & Model 5 & Model 6 \\
\hline DELTACO2 & $\begin{array}{c}-31.7559 * * * \\
{[7.3145]}\end{array}$ & $\begin{array}{c}-31.8168^{* * *} \\
{[7.3349]}\end{array}$ & $\begin{array}{c}-66.2760 * \\
{[34.4802]}\end{array}$ & $\begin{array}{c}-67.2307^{* *} \\
{[32.0351]}\end{array}$ & $\begin{array}{c}-67.1948^{* *} \\
{[32.1056]}\end{array}$ & $\begin{array}{c}-116.407 \\
{[125.0350]}\end{array}$ \\
\hline DELTACO2^2 & $\begin{array}{c}-9020 \\
{[6243.3670]}\end{array}$ & $\begin{array}{c}-8880 \\
{[6245.1541]}\end{array}$ & $\begin{array}{c}-9580 \\
{[6263.9008]}\end{array}$ & $\begin{array}{c}-59,500^{* *} \\
{[28,500]}\end{array}$ & $\begin{array}{c}-59,500 * * \\
{[28,400]}\end{array}$ & $\begin{array}{c}-59,100 * * \\
{[27,900]}\end{array}$ \\
\hline SIZE & $\begin{array}{c}0.0106^{* * *} \\
{[0.0010]}\end{array}$ & $\begin{array}{c}0.0102^{* * *} \\
{[0.0010]}\end{array}$ & $\begin{array}{c}0.0101 * * * \\
{[0.0010]}\end{array}$ & $\begin{array}{c}0.0340^{* * *} \\
{[0.0048]}\end{array}$ & $\begin{array}{c}0.0326^{* * *} \\
{[0.0048]}\end{array}$ & $\begin{array}{c}0.0326^{* * *} \\
{[0.0048]}\end{array}$ \\
\hline LEVERAGE & $\begin{array}{c}-0.0217^{* *} \\
{[0.0110]}\end{array}$ & $\begin{array}{c}-0.0225^{* *} \\
{[0.0110]}\end{array}$ & $\begin{array}{c}-0.0225^{* *} \\
{[0.0110]}\end{array}$ & $\begin{array}{c}0.0916 \\
{[0.0585]}\end{array}$ & $\begin{array}{c}0.0896 \\
{[0.0585]}\end{array}$ & $\begin{array}{c}0.0897 \\
{[0.0585]}\end{array}$ \\
\hline CAPINT & $\begin{array}{c}-0.0113^{* * *} \\
{[0.0019]}\end{array}$ & $\begin{array}{c}-0.0112^{* * *} \\
{[0.0019]}\end{array}$ & $\begin{array}{c}-0.0113^{* * *} \\
{[0.0019]}\end{array}$ & $\begin{array}{c}-0.0279 * * * \\
{[0.0059]}\end{array}$ & $\begin{array}{c}-0.0278^{* * *} \\
{[0.0059]}\end{array}$ & $\begin{array}{c}-0.0278^{* * *} \\
{[0.0059]}\end{array}$ \\
\hline DELTASALES & $\begin{array}{c}0.0640^{* * * *} \\
{[0.0060]}\end{array}$ & $\begin{array}{c}0.0645^{* * *} \\
{[0.0060]}\end{array}$ & $\begin{array}{c}0.0645^{* * *} \\
{[0.0060]}\end{array}$ & $\begin{array}{c}0.1269 * * * \\
{[0.0227]}\end{array}$ & $\begin{array}{c}0.1277^{* * *} \\
{[0.0228]}\end{array}$ & $\begin{array}{c}0.1274^{* * *} \\
{[0.0229]}\end{array}$ \\
\hline CASHFLOW & $\begin{array}{c}0.1320 * * * \\
{[0.0201]}\end{array}$ & $\begin{array}{c}0.1318^{* * *} \\
{[0.0200]}\end{array}$ & $\begin{array}{c}0.1320 * * * \\
{[0.0199]}\end{array}$ & $\begin{array}{c}0.3362^{* * * *} \\
{[0.0634]}\end{array}$ & $\begin{array}{c}0.3356^{* * * *} \\
{[0.0633]}\end{array}$ & $\begin{array}{c}0.3359 * * * \\
{[0.0634]}\end{array}$ \\
\hline GDPGROWTH & $\begin{array}{c}0.0063 \\
{[0.0513]}\end{array}$ & $\begin{array}{c}0.0036 \\
{[0.0511]}\end{array}$ & $\begin{array}{l}-0.0032 \\
{[0.0509]}\end{array}$ & $\begin{array}{l}-0.1490 \\
{[0.2117]}\end{array}$ & $\begin{array}{l}-0.1596 \\
{[0.2124]}\end{array}$ & $\begin{array}{l}-0.1616 \\
{[0.2118]}\end{array}$ \\
\hline CO2EMISSION & & $\begin{array}{c}0.0190 \\
{[0.0252]}\end{array}$ & $\begin{array}{c}0.0196 \\
{[0.0253]}\end{array}$ & & $\begin{array}{l}0.1755^{* *} \\
{[0.0802]}\end{array}$ & $\begin{array}{l}0.1762 * * \\
{[0.0800]}\end{array}$ \\
\hline$L E G A L$ & & $\begin{array}{c}0.0011 \\
{[0.0030]}\end{array}$ & $\begin{array}{c}0.0012 \\
{[0.0029]}\end{array}$ & & $\begin{array}{c}0.0122 \\
{[0.0126]}\end{array}$ & $\begin{array}{c}0.0126 \\
{[0.0125]}\end{array}$ \\
\hline$E S G$ & & $\begin{array}{c}0.0002 * * * \\
{[0.0001]}\end{array}$ & $\begin{array}{c}0.0002^{* * *} \\
{[0.0001]}\end{array}$ & & $\begin{array}{l}0.0006^{*} \\
{[0.0003]}\end{array}$ & $\begin{array}{l}0.0006 \text { * } \\
{[0.0003]}\end{array}$ \\
\hline DELTACO2_X_CO2 & & & $\begin{array}{l}-56.6007 \\
{[46.3057]}\end{array}$ & & & $\begin{array}{c}39.6869 \\
{[180.2594]}\end{array}$ \\
\hline DELTACO2_X_LEGAL & & & $\begin{array}{c}10.4208 \\
{[18.6720]}\end{array}$ & & & $\begin{array}{c}46.9072 \\
{[77.3637]}\end{array}$ \\
\hline DELTACO2_X_ESG & & & $\begin{array}{l}0.8079 * \\
{[0.4263]}\end{array}$ & & & $\begin{array}{c}0.0477 \\
{[1.9778]}\end{array}$ \\
\hline CONSTANT & $\begin{array}{c}-0.1729 * * * \\
{[0.0267]}\end{array}$ & $\begin{array}{c}-0.1735^{* * *} \\
{[0.0315]}\end{array}$ & $\begin{array}{c}-0.1741^{* * *} \\
{[0.0316]}\end{array}$ & $\begin{array}{c}-0.7536^{* * *} \\
{[0.1208]}\end{array}$ & $\begin{array}{c}-0.7841^{* * *} \\
{[0.1339]}\end{array}$ & $\begin{array}{c}-0.7832 \text { **** } \\
{[0.1340]}\end{array}$ \\
\hline FIXED EFFECTS & Yes & Yes & Yes & Yes & Yes & Yes \\
\hline Adjusted R-squared & 0.4737 & 0.4749 & 0.4753 & 0.2035 & 0.2040 & 0.2038 \\
\hline Observations & 9265 & 9265 & 9265 & 9265 & 9265 & 9265 \\
\hline
\end{tabular}

The table provides the estimates of the OLS regression for ROA and ROE. The matrix includes the coefficients of the independent variables DELTACO2 and DELTACO2'2 that are lagged with $\mathrm{t}-1$, the dependent variables ROA and ROE, the control variables SIZE, LEVERAGE, CAPINT, DELTASALES, CASHFLOW, and GDPGROWTH, and the moderating variables CO2EMISSION, LEGAL, and ESG. The variable definitions can be found in Table A1. The models use industry, year, and country fixed effects. Robust firm-level clustered standard errors are presented in square brackets. The symbols $* * * * *, *$ denote statistical significance at the $1 \%, 5 \%$, and $10 \%$ levels. 
The third profitability measurement for CFP is ROS, which represents the firm's return on sales and is calculated by dividing the net income by the net sales for firm i in year $t$. The results for the performed OLS regression on the dependent variable ROE are presented in Table 4 under Models 7-9. The variable DELTACO2 in Models 7 and 8 show a negative significant relationship between carbon mitigation and $\operatorname{ROE}(\beta 7=-78.2878, \beta 8=-78.0989$, $p=<0.05)$, suggesting that firms that reduce their emissions had an overall better return on equity. The results in Model 9 provide a negative and significant relation $(\beta 9=-420.4692$, $p=>0.1$ ), with a lower significance level compared to Models 7 and 9 . The magnitude of the coefficients for the variable DELTACO2 in the results show that there is a larger effect of carbon emissions reduction on ROS compared to ROA and ROE. For the variable DELTACO2^2, the results in Models 7-9 are statistically insignificant, which provides no evidence for a curvilinear relation between carbon emissions reduction and CFP. The results for the moderating variables CO2EMISSION, ESG, and LEGAL are insignificant in Model 8. The coefficients for the variables DELTACO2 X ESG, DELTACO2 X LEGAL, and DELTACO2 $X \mathrm{CO} 2$ are in Model 9 all positive but insignificant providing no evidence for a moderating effect on the relation between carbon mitigation and ROS.

Table 4. Regression analysis on ROS.

\begin{tabular}{|c|c|c|c|}
\hline CFP Measure & ROS & ROS & ROS \\
\hline Variable & Model 7 & Model 8 & Model 9 \\
\hline DELTACO2 & $\begin{array}{c}-78.2878^{* *} \\
{[36.5323]}\end{array}$ & $\begin{array}{c}-78.0989 * * \\
{[36.4607]}\end{array}$ & $\begin{array}{c}-420.4692 * \\
{[248.6165]}\end{array}$ \\
\hline DELTACO2^2 & $\begin{array}{l}-50,300 \\
{[49,700]}\end{array}$ & $\begin{array}{l}-50,600 \\
{[49,900]}\end{array}$ & $\begin{array}{l}-49,900 \\
{[48,100]}\end{array}$ \\
\hline SIZE & $\begin{array}{c}0.0099 * * * \\
{[0.0018]}\end{array}$ & $\begin{array}{c}0.0099 * * * \\
{[0.0017]}\end{array}$ & $\begin{array}{c}0.0099 * * * \\
{[0.0017]}\end{array}$ \\
\hline LEVERAGE & $\begin{array}{c}-0.0901^{* * *} \\
{[0.0251]}\end{array}$ & $\begin{array}{c}-0.0896^{* * *} \\
{[0.0248]}\end{array}$ & $\begin{array}{c}-0.0904^{* * *} \\
{[0.0246]}\end{array}$ \\
\hline CAPINT & $\begin{array}{c}-0.0214^{* * *} \\
{[0.0032]}\end{array}$ & $\begin{array}{c}-0.0214^{* * *} \\
{[0.0032]}\end{array}$ & $\begin{array}{c}-0.0214^{* * *} \\
{[0.0032]}\end{array}$ \\
\hline DELTASALES & $\begin{array}{c}0.0763 * * * \\
{[0.0239]}\end{array}$ & $\begin{array}{c}0.0759 * * * \\
{[0.0239]}\end{array}$ & $\begin{array}{c}0.0762 * * * \\
{[0.0239]}\end{array}$ \\
\hline CASHFLOW & $\begin{array}{c}0.6838^{* * *} \\
{[0.0506]}\end{array}$ & $\begin{array}{c}0.6839 * * * \\
{[0.0507]}\end{array}$ & $\begin{array}{c}0.6846^{* * *} \\
{[0.0500]}\end{array}$ \\
\hline GDPGROWTH & $\begin{array}{l}-0.1122 \\
{[0.1641]}\end{array}$ & $\begin{array}{l}-0.1139 \\
{[0.1636]}\end{array}$ & $\begin{array}{l}-0.1143 \\
{[0.1640]}\end{array}$ \\
\hline CO2EMISSION & & $\begin{array}{c}0.1816 \\
{[0.1264]}\end{array}$ & $\begin{array}{c}0.1880 \\
{[0.1276]}\end{array}$ \\
\hline$L E G A L$ & & $\begin{array}{c}0.0075 \\
{[0.0083]}\end{array}$ & $\begin{array}{c}0.0069 \\
{[0.0078]}\end{array}$ \\
\hline$E S G$ & & $\begin{array}{c}0.0000 \\
{[0.0002]}\end{array}$ & $\begin{array}{c}0.0000 \\
{[0.0002]}\end{array}$ \\
\hline DELTACO2_X_CO2 & & & $\begin{array}{l}5.3308 \\
{[3.3611]}\end{array}$ \\
\hline DELTACO2_X_LEGAL & & & $\begin{array}{c}-6.0941 \\
{[62.3319]}\end{array}$ \\
\hline DELTACO2_X_ESG & & & $\begin{array}{c}173.6231 \\
{[168.6131]}\end{array}$ \\
\hline CONSTANT & $\begin{array}{c}-0.2803^{* * *} \\
{[0.0792]}\end{array}$ & $\begin{array}{c}-0.3293^{* * *} \\
{[0.1143]}\end{array}$ & $\begin{array}{c}-0.3367 * * * \\
{[0.1154]}\end{array}$ \\
\hline FIXED EFFECTS & Yes & Yes & Yes \\
\hline Adjusted R-squared & 0.8242 & 0.8242 & 0.8249 \\
\hline Observations & 9265 & 9265 & 9265 \\
\hline
\end{tabular}

The table provides estimates of the OLS regression for ROS. The matrix includes the coefficients of the independent variables DELTACO2 and DELTACO2^2 that are lagged with $\mathrm{t}-1$, the dependent variable ROS, the control variables SIZE, LEVERAGE, CAPINT, DELTASALES, CASHFLOW, and GDPGROWTH and the moderating variables CO2EMISSION, LEGAL, and ESG. The variable definitions can be found in Table A1. The models use industry, year, and country fixed effects. Robust firm-level clustered standard errors are presented in square brackets. The symbols ${ }^{* * *}, * *, *$ denote statistical significance at the $1 \%, 5 \%$, and $10 \%$ levels. 
Overall, the results indicate a positive relationship between profitability and carbon emissions reduction: firms that are decreasing their emissions have an overall better CFP. These findings are in line with the results of Gallego-Alvarez et al. [12] and partly with Lewandowski [7] who found similar results for ROS. The results also show evidence for a curvilinear relation between carbon emissions reduction and CFP for the variable ROE, but not for the variables ROA and ROS. The results for the interaction variables that represent the alternative hypotheses only provide a positive effect of ESG on the relation between carbon emissions reduction and ROA. No significant relationship is shown for the other interaction variables.

\subsection{Regression Analysis on Stock Market Performance and Liquidity}

Now, we provide the results of the OLS regressions on the relation between carbon emissions reduction and CFP. CFP is separated into two dependent variables, TOBIN, and $C R$, which are measurements of stock market performance and liquidity respectively. As to all these dependent variables, again, three different models are provided. Model 1 only contains the dependent variable and the control variables, Model 2 introduces the moderating variables, and Model 3 introduces the created interaction variables for the moderating effects. Table 5 contains the baseline model results. The regression analysis provides insight into the relationship between CFP and carbon emissions reduction without the interaction variables.

The dependent variable TOBIN represents the stock market performance indicator Tobin's Q used in this research and is represented in Models 10-12. The coefficients for the main independent variable DELTACO2 are all negative but insignificant, showing no evidence for a relationship between CFP and carbon emissions reduction. These results contradict the findings of Lewandowski [7], who found a negative relation, and Delmas et al. [6], who found a positive relation but used a different methodology to measure the corporate environmental performance. The positive and significant results for the variable DELTACO2^2 provide evidence for a curvilinear relation. The country-level control variable GDPGROWTH shows significant positive coefficients $(\beta 10=2.2703, \beta 11=2.3406$, $\beta 12=2.1651, p=<0.05)$, providing evidence for the country's economic development and the CFP of firms. Model 2 introduces the moderating variables CO2EMISSION, ESG, and LEGAL. The coefficients for the variable CO2EMISSION show that the overall carbon emissions for firms are positively related to the CFP $(\beta 11=2.6519, \beta 12=2.6535, p=<0.01)$, which suggests that companies that operate in more polluting countries have a better stock market performance. The results for the variable ESG are negative but insignificant, indicating that the firm's level of responsibility has no effect on CFP measured with Tobin's Q. The negative and significant coefficients for the variable $L E G A L(\beta 11=-0.1473, \beta 12=-0.1405$, $p=<0.01$ ) show that the Tobin's $\mathrm{Q}$ of firms that operate in a country with carbon emissions legislation is impacted negatively. The results for the variables DELTACO2 X ESG, DELTACO2 X LEGAL, and DELTACO2 X CO2 are insignificant and provide no evidence for a moderating effect on the relationship between carbon emissions reduction and Tobin's $Q$.

The liquidity measurement for CFP within this research is $C R$, which represents the firm's current ratio, which is calculated by dividing the current assets by the current liabilities for firm $\mathrm{i}$ in year $\mathrm{t}$. The results for the OLS regressions on the dependent variable $C R$ are presented in Table 5 under Models 13-15. As to the variable DELTACO2, Models 13,14 , and 15 show a positive but insignificant relation between carbon mitigation and the current ratio $(\beta 13=117.9604, \beta 14=118.7263, \beta 15=355.6842, p=<0.05)$, suggesting no relation between carbon emissions reduction and the firm's liquidity. For the variable DELTACO2^2, the results in Models 13-15 are statistically insignificant, which provides no evidence for the curvilinear relation between carbon emissions reduction and CFP. The coefficients for the variable GDPGROWTH are also negative but insignificant. Model 14 introduces the moderating variables as control variables. For the moderating variables CO2EMISSION and LEGAL, the results are insignificant. The coefficients for the variable ESG $(\beta 14=-0.0019, \beta 15=-0.0019, p=<0.1)$ show a significant negative relation, suggest- 
ing that more responsible firms have a lower liquidity. Model 15 introduces the interaction variables to see whether these variables influence the relation between carbon emissions reduction and CR. The coefficients for the variables DELTACO2 X ESG, DELTACO2 X $L E G A L$, and DELTACO2 X CO2 are insignificant, providing no evidence for a moderating effect on the relation between carbon mitigation and the current ratio.

Table 5. Regression analysis on TOBIN and CR.

\begin{tabular}{|c|c|c|c|c|c|c|}
\hline CFP Measure & TOBIN & TOBIN & TOBIN & CR & CR & CR \\
\hline Variable & Model 10 & Model 11 & Model 12 & Model 13 & Model 14 & Model 15 \\
\hline DELTACO2 & $\begin{array}{l}-174.3528 \\
{[130.1209]}\end{array}$ & $\begin{array}{c}-176.812 \\
{[129.9563}\end{array}$ & $\begin{array}{l}-462.5821 \\
{[8268382]}\end{array}$ & $\begin{array}{l}117.9604 \\
{[80.4411]}\end{array}$ & $\begin{array}{l}119.8409 \\
{[80.3802}\end{array}$ & $\begin{array}{c}355.6842 \\
{[443.6451]}\end{array}$ \\
\hline DELTACO2^2 & $\begin{array}{l}291,000 * * \\
{[147,000]}\end{array}$ & $\begin{array}{l}295,000 * * \\
{[147,000]}\end{array}$ & $\begin{array}{l}279,000 \text { * } \\
{[148,000]}\end{array}$ & $\begin{array}{c}45,300 \\
{[87,700]}\end{array}$ & $\begin{array}{c}41,700 \\
{[87,300]}\end{array}$ & $\begin{array}{c}38,100 \\
{[87,300]}\end{array}$ \\
\hline SIZE & $\begin{array}{c}0.3044^{* * * *} \\
{[0.0256]}\end{array}$ & $\begin{array}{c}0.3101^{* * *} \\
{[0.0262]}\end{array}$ & $\begin{array}{c}0.3092^{* * *} \\
{[0.0261]}\end{array}$ & $\begin{array}{c}-0.0216 \text { * } \\
{[0.0116]}\end{array}$ & $\begin{array}{l}-0.0176 \\
{[0.0119]}\end{array}$ & $\begin{array}{l}-0.0175 \\
{[0.0119]}\end{array}$ \\
\hline LEVERAGE & $\begin{array}{l}0.6971^{* *} \\
{[0.2705]}\end{array}$ & $\begin{array}{c}0.7004^{* * *} \\
{[0.2700]}\end{array}$ & $\begin{array}{c}0.7038^{* * * *} \\
{[0.2705]}\end{array}$ & $\begin{array}{c}-0.7259^{* * *} \\
{[0.1580]}\end{array}$ & $\begin{array}{c}-0.7159^{* * *} \\
{[0.1574]}\end{array}$ & $\begin{array}{c}-0.7165^{* * * *} \\
{[0.1574]}\end{array}$ \\
\hline CAPINT & $\begin{array}{c}-0.0646^{* * *} \\
{[0.0137]}\end{array}$ & $\begin{array}{c}-0.0650 * * * \\
{[0.0137]}\end{array}$ & $\begin{array}{c}-0.0654^{* * *} \\
{[0.0135]}\end{array}$ & $\begin{array}{c}-0.0148^{* *} \\
{[0.0066]}\end{array}$ & $\begin{array}{c}-0.0150 * * \\
{[0.0066]}\end{array}$ & $\begin{array}{c}-0.0149 * * \\
{[0.0066]}\end{array}$ \\
\hline DELTASALES & $\begin{array}{c}0.1957 \\
{[0.1194]}\end{array}$ & $\begin{array}{l}0.1972 * \\
{[0.1190]}\end{array}$ & $\begin{array}{l}0.1956^{*} \\
{[0.1188]}\end{array}$ & $\begin{array}{l}-0.0055 \\
{[0.0669]}\end{array}$ & $\begin{array}{l}-0.0121 \\
{[0.0663]}\end{array}$ & $\begin{array}{l}-0.0109 \\
{[0.0664]}\end{array}$ \\
\hline CASHFLOW & $\begin{array}{c}0.7730 * * * \\
{[0.1500]}\end{array}$ & $\begin{array}{c}0.7749 * * * \\
{[0.1500]}\end{array}$ & $\begin{array}{c}0.7787^{* * * *} \\
{[0.1487]}\end{array}$ & $\begin{array}{c}0.13244^{* *} \\
{[0.0646]}\end{array}$ & $\begin{array}{c}0.1342 * * \\
{[0.647]}\end{array}$ & $\begin{array}{l}0.1329^{* *} \\
{[0.0646]}\end{array}$ \\
\hline GDPGROWTH & $\begin{array}{l}2.2703 * * \\
{[0.9520]}\end{array}$ & $\begin{array}{l}2.3406^{* *} \\
{[0.9552]}\end{array}$ & $\begin{array}{l}2.16511^{* *} \\
{[0.9401]}\end{array}$ & $\begin{array}{l}-0.5644 \\
{[0.7016]}\end{array}$ & $\begin{array}{l}-0.5570 \\
{[0.7020]}\end{array}$ & $\begin{array}{l}-0.5607 \\
{[0.7026]}\end{array}$ \\
\hline CO2EMISSION & & $\begin{array}{c}2.6519^{* * *} \\
{[0.8503]}\end{array}$ & $\begin{array}{c}2.6535^{* * *} \\
{[0.8397]}\end{array}$ & & $\begin{array}{l}-0.4147 \\
{[0.4715]}\end{array}$ & $\begin{array}{l}-0.4183 \\
{[0.4727]}\end{array}$ \\
\hline$L E G A L$ & & $\begin{array}{c}-0.1473 * * * \\
{[0.0534]}\end{array}$ & $\begin{array}{c}-0.1405^{* * *} \\
{[0.0527]}\end{array}$ & & $\begin{array}{c}0.0483 \\
{[0.0336]}\end{array}$ & $\begin{array}{c}0.4445 \\
{[5.7339]}\end{array}$ \\
\hline$E S G$ & & $\begin{array}{l}-0.0024 \\
{[0.0017]}\end{array}$ & $\begin{array}{l}-0.0023 \\
{[0.0017]}\end{array}$ & & $\begin{array}{c}-0.0019^{*} \\
{[0.0011]}\end{array}$ & $\begin{array}{c}-0.0019 * \\
{[0.0011]}\end{array}$ \\
\hline DELTACO2_X_CO2 & & & $\begin{array}{c}-1570 \\
{[1770.3055]}\end{array}$ & & & $\begin{array}{l}-342.7303 \\
{[512.5218]}\end{array}$ \\
\hline DELTACO2_X_LEGAL & & & $\begin{array}{c}561.3319 \\
{[375.6054]}\end{array}$ & & & $\begin{array}{l}-210.6681 \\
{[201.9915]}\end{array}$ \\
\hline DELTACO2_X_ESG & & & $\begin{array}{c}6.5853 \\
{[8.4203]}\end{array}$ & & & $\begin{array}{c}0.0468 \\
{[0.0335]}\end{array}$ \\
\hline CONSTANT & $\begin{array}{c}-6.3711^{* * *} \\
{[0.7133]}\end{array}$ & $\begin{array}{c}-7.3371^{* * *} \\
{[0.9026]}\end{array}$ & $\begin{array}{c}-7.3255^{* * *} \\
{[0.8971]}\end{array}$ & $\begin{array}{c}1.4722 * * * \\
{[0.3688]}\end{array}$ & $\begin{array}{c}1.5541^{* * *} \\
{[0.4794]}\end{array}$ & $\begin{array}{c}1.5963 * * * \\
{[0.4833]}\end{array}$ \\
\hline FIXED EFFECTS & Yes & Yes & Yes & Yes & Yes & Yes \\
\hline Adjusted R-sq & 0.4384 & 0.4392 & 0.4399 & 0.4056 & 0.4064 & 0.4064 \\
\hline Observations & 9265 & 9265 & 9265 & 9265 & 9265 & 9265 \\
\hline
\end{tabular}

The table provides the estimates of the OLS regression for TOBIN and $C R$. The matrix shows the coefficients of the independent variables DELTACO2 and DELTACO2^2 that are lagged with $\mathrm{t}-1$, the dependent variables TOBIN and $C R$, the control variables SIZE, LEVERAGE, CAPINT, DELTASALES, CASHFLOW, and GDPGROWTH and the moderating variables CO2EMISSION, LEGAL, and ESG. The variable definitions can be found in Table A1. The models use industry, year, and country fixed effects. Robust firm-level clustered standard errors are presented in square brackets. The symbols $* * * * *, *$ denote statistical significance at the $1 \%, 5 \%$, and $10 \%$ levels.

\section{Conclusions and Recommendations}

\subsection{Conclusions}

In this article, we address the "does it pay to be green" issue by investigating whether carbon emissions reduction influences CFP. By including country characteristics and a large cross-country sample, this paper fills a gap in the literature, as suggested by GallegoAlvarez et al. [12], that future research should include the effect of country-level characteristics on the relationship between carbon emissions and CFP. We performed OLS regressions on a sample including 9265 firm year observations covering 53 countries and 1785 firms over the years 2004-2019. The regression analysis was used to investigate whether carbon emissions reduction in firm $\mathrm{i}$ in year $\mathrm{t}$ influences CFP. Our main findings are that carbon 
emissions reduction improves the short-term profitability in terms of ROA, ROE, and ROS, but it does not influence the stock market performance in terms of Tobin's $Q$ and (new in research) the liquidity in terms of CR. We provide evidence for a curvilinear relation between carbon emissions reduction and the firm's ROS. The results on the first hypothesis are therefore mixed.

We extend the analysis by implementing three moderating variables to see whether these variables strengthen or weaken the relationship between carbon mitigation and CFP. CO2EMISSION measures the effect of a country's overall carbon emissions, LEGAL measures whether the presence of carbon emissions legislation in a country, and ESG measures whether the firm's responsibility score influences the relationship between carbon emissions reduction and CFP. For the moderating variables CO2EMISSION and LEGAL, no significant results were found. These results reject the second and third hypotheses of the research. The results for the variable ESG provide evidence for a weak moderating effect of responsibility on the relationship between carbon emissions reductions and return on assets, indicating that the ROA of more responsible firms benefits more from carbon emissions reduction, compared to firms with a lower ESG score. These findings provide evidence for the fourth hypothesis.

\subsection{Recommendations}

The number of observations in this study is 9265, which is higher than with any prior research. However, still, individual observations may have biased the overall results, especially regarding the country characteristics. The Thomson Reuters Database provides estimation data, but replacement of real carbon emissions by estimated ones weakens empirical results since Eikon uses different estimation techniques across different firms. Future researchers may want to gather a larger sample to analyze the effect of country characteristics on the relationship between carbon emissions reduction and CFP.

As a robustness check, the variable CASH_FLOW, being strongly correlated to the two variables ROS and CAPINT, was excluded from the analysis. We found a decrease in the adjusted R-squared for all of the models. In addition, a change in sign of the carbon emissions variable and a decrease in significance occur for the variables ROA and ROS as compared to the original results. These findings show that the original results are valid and that CASH_FLOW needs to be included in the model, but also indicate that various model specifications may make a difference and should be traded off against each other.

We include the presence of carbon emissions legislation as an interaction variable. However, firms can have multiple other incentives to reduce their emissions, such as the pressure of stakeholders. Future research could focus on the incentives firms have to reduce their emissions, to see whether this influences the relation between carbon emissions reduction and $\mathrm{CPF}$.

We show that carbon emissions reduction does not hurt but benefits the short-term profitability of firms and that carbon reduction has a neutral relationship with the stock market performance and liquidity of firms. In general, it is advisable for companies to benefit the most out of corporate carbon emission targets integration with corporate financial performance goals. However, specific country characteristics might be influencing the results.

Our study provides the first step into the implementation of a country-level characteristics analysis. As a second step, differences between countries with sufficient observations can be studied. We single out countries with more than 20 firms in the sample and arrive at no less than 39 countries with 9175 observations (see Table A3 in Appendix C). Interestingly, DELTACO2 is the highest for Portugal, at a distance followed by Canada, Italy, Brazil, and Ireland, whereas Luxembourg, the Netherlands, Singapore, and especially Indonesia are shown to have the lowest values. Future research may extend our approach by performing more in-depth analysis to understand the differences in the relation between carbon emissions reduction and CFP among different countries and continents.

We also ran regressions using carbon emissions as the dependent variable. In doing so, we, for instance, found a negative sign for SIZE at times. This could mean that larger firms 
assign less resources to carbon emission reduction and do not receive benefits from their efforts, however, other explanations can also be thought of. Moreover, dynamic effects and interactions between variables may occur. For example, whereas ESG outlays used to be considered as costs, they may be considered as investments nowadays. However, this effect has not yet brought empirical evidence and thus warrants further research. This longitudinal research focuses on observable trends and not on changes or interactions in time. Nevertheless, we agree that a dynamic modeling approach could add value to studies such as the current one and therefore should be called for.

Our results indicate that regulatory pressures to reduce a firm's emissions do not per se influence the relation between carbon emissions reduction and CFP, whereas, in addition, the overall carbon emissions of a country do not influence the relation between their reduction and CFP. While regulatory pressure in, e.g., EU countries is unfolding, the implementation thereof still seems to be slow and low performing. Still, there is more push towards regulations introducing responsible investments, bringing about the evolution of nonfinancial value concepts. In this context, capitalizing on currently available data for policy decision-making is as important as setting new standards for green performance systems.

Author Contributions: R.v.E.; writing—original draft preparation, R.K.; writing—review and editing, W.W.; writing-review and editing. All authors have read and agreed to this version of the manuscript.

Funding: This research received no external funding.

Institutional Review Board Statement: Not applicable.

Informed Consent Statement: Not applicable.

Data Availability Statement: Specific data used are drawn from publically available sources.

Conflicts of Interest: The authors declare no conflict of interest.

Appendix A. Overview of Variables

Table A1. Overview of variables.

\begin{tabular}{|c|c|c|}
\hline Variable & Description & Used by \\
\hline DELTACO2 & $\begin{array}{l}\text { Difference in carbon emission divided by the overall sales compared to the } \\
\text { previous year, with the sum of Scope } 1 \text { and Scope } 2 \text { emissions being measured } \\
\text { in tonnes }\end{array}$ & Lewandowski [7] \\
\hline DELTACO2^2 & The squared function of DELTACO2 to account for a curvilinear relationship & Lewandowski [7] \\
\hline$R O A$ & $\begin{array}{l}\text { The return on assets, calculated by dividing the operating income by the total } \\
\text { assets at the end of the financial year }\end{array}$ & Gallego-Alvarez et al. [12] \\
\hline ROS & $\begin{array}{l}\text { The return on sales, calculated by dividing the net income by the total sales at } \\
\text { the end of the financial year }\end{array}$ & Lewandowski [7] \\
\hline$R O E$ & $\begin{array}{l}\text { The return on equity, calculated by dividing the net income by the total equity } \\
\text { at the end of the financial year }\end{array}$ & Lewandowski [7] \\
\hline TOBIN & $\begin{array}{c}\text { The Tobin's Q, calculated as: (market capitalization + current liabilities + long } \\
\text { term debts-current assets)/total assets }\end{array}$ & Delmas et al. [6] \\
\hline$C R$ & The current ratio, calculated as current assets scaled by the total liabilities & Durrah et al. [6] \\
\hline SIZE & Measured as the natural logarithm of the market capitalization of the company & Lewandowski [7] \\
\hline LEVERAGE & Calculated by dividing the long-term debts by the total assets & Lewandowski [7] \\
\hline CAPINT & Capital intensity calculated by dividing the total assets by the total sales & Lewandowski [7] \\
\hline DELTASALES & Ratio of the difference in sales compared to the previous years & Lewandowski [7] \\
\hline CASHFLOW & The firm's free cash flow as ratio of the annual net sales & Lewandowski [7] \\
\hline GDPGROWTH & Measured as the GDP per capita of the home country of the firms & Iannotta et al. [13] \\
\hline CO2EMISSION & $\begin{array}{c}\text { Measures the overall carbon emissions of the home country as ratio of the } \\
\text { overall GDP }\end{array}$ & Alonso-Martinez [17] \\
\hline LEGAL & $\begin{array}{c}\text { Dummy variable that indicates the presence or participation within a trading } \\
\text { emission scheme or the presence of carbon taxation regulation within in the } \\
\text { home country of the firm }\end{array}$ & Galama \& Scholtens [8] \\
\hline ESG & The ESG score of firm i in year $\mathrm{t}$ to measure the firm's level of responsibility. & Sariannidis [32] \\
\hline
\end{tabular}

Overview of the variables used; for each of the variables, a description, source, and data source is presented. 


\section{Appendix B. Overview of Carbon Emissions Legislation by Country}

Table A2. Carbon emissions legislation by country.

\begin{tabular}{|c|c|c|c|c|c|}
\hline Country & $\mathbf{N}$ & ETS from & ETS Till & Carbon Emissions Tax from & Carbon Emissions Tax Till \\
\hline Argentina & 9 & - & - & 2018 & Still active \\
\hline Australia & 522 & 2012 & Still active & - & - \\
\hline Austria & 54 & 2005 & Still active & - & - \\
\hline Belgium & 80 & 2005 & Still active & - & - \\
\hline Bermuda & 56 & - & - & - & - \\
\hline Brazil & 35 & - & - & - & - \\
\hline Canada & 382 & 2018 & Still active & 2018 & Still active \\
\hline Cayman Islands & 35 & - & - & - & - \\
\hline Chile & 16 & - & - & 2017 & Still active \\
\hline China & 96 & - & - & - & - \\
\hline Colombia & 18 & - & - & 2017 & Still active \\
\hline Cyprus & 1 & 2005 & Still active & - & - \\
\hline Denmark & 126 & 2005 & Still active & 2004 & Still active \\
\hline Finland & 129 & 2005 & Still active & 2004 & Still active \\
\hline France & 536 & 2005 & Still active & 2014 & Still active \\
\hline Germany & 347 & 2005 & Still active & - & - \\
\hline Greece & 39 & 2005 & Still active & - & - \\
\hline Hong Kong SAR. China & 111 & - & - & _ & _ \\
\hline Hungary & 11 & 2005 & Still active & - & - \\
\hline India & 113 & - & - & - & - \\
\hline Indonesia & 27 & - & - & - & - \\
\hline Ireland & 29 & 2005 & Still active & - & - \\
\hline Israel & 38 & - & - & - & - \\
\hline Italy & 142 & 2005 & Still active & - & - \\
\hline Japan & 1775 & - & - & 2012 & Still active \\
\hline Kazakhstan & 3 & 2013 & Still active & - & - \\
\hline Kenya & 2 & - & - & - & - \\
\hline Korea. Rep. & 113 & - & - & - & - \\
\hline Liberia & 1 & - & - & - & - \\
\hline Luxembourg & 27 & 2005 & Still active & - & - \\
\hline Malaysia & 29 & - & - & _ & _ \\
\hline Mexico & 93 & - & - & 2014 & Still active \\
\hline Morocco & 1 & - & & - & - \\
\hline Netherlands & 189 & 2005 & Still active & _ & - \\
\hline New Zealand & 57 & 2008 & Still active & - & - \\
\hline Norway & 48 & 2005 & Still active & 2004 & Still active \\
\hline Panama & 2 & - & - & - & - \\
\hline Papua New Guinea & 15 & - & - & - & - \\
\hline Philippines & 55 & - & - & - & - \\
\hline Poland & 23 & 2005 & Still active & 2004 & Still active \\
\hline Portugal & 46 & 2005 & Still active & 2015 & Still active \\
\hline Russian Federation & 28 & - & - & - & - \\
\hline Saudi Arabia & 5 & - & - & - & - \\
\hline Singapore & 56 & - & - & 2019 & Still active \\
\hline South Africa & 350 & - & - & 2019 & Still active \\
\hline Spain & 196 & 2005 & Still active & 2014 & Still active \\
\hline Sweden & 222 & 2005 & Still active & 2004 & Still active \\
\hline Switzerland & 256 & 2008 & Still active & 2008 & Still active \\
\hline Thailand & 22 & - & - & - & - \\
\hline Turkey & 3 & _ & _- & _ & _ \\
\hline United Arab Emirates & 3 & - & - & - & - \\
\hline United Kingdom & 1570 & 2005 & Still active & - & - \\
\hline United States & 1123 & 2009 & Still active & - & - \\
\hline Total & 9265 & & & & \\
\hline
\end{tabular}

Overview of the presence or participation in an emission trading scheme or carbon taxation within a country. 


\section{Appendix C. Descriptive Statistics for the Most Important Countries}

Table A3. Descriptive statistics by country.

\begin{tabular}{|c|c|c|c|c|c|c|c|c|c|c|}
\hline Country & $\mathbf{N}$ & DELTACO2 & ROA & ROS & ROE & TOBIN & $\mathrm{CR}$ & CO2EMISSION & LEGAL & ESG \\
\hline Australia & 522 & -0.000017300 & 0.055 & 0.044 & 0.051 & 1.298 & 1.546 & 0.474 & 0.761 & 52.228 \\
\hline Austria & 54 & -0.000000246 & 0.049 & 0.044 & 0.069 & 0.934 & 1.186 & 0.207 & 1.000 & 56.032 \\
\hline Belgium & 80 & -0.000021000 & 0.076 & 0.053 & 0.114 & 1.052 & 1.205 & 0.272 & 1.000 & 57.582 \\
\hline Bermuda & 56 & -0.000003530 & 0.010 & 0.045 & -0.024 & 2.414 & 1.653 & 0.131 & 0.000 & 52.274 \\
\hline Brazil & 35 & -0.000023800 & 0.047 & 0.026 & -0.025 & 0.563 & 1.575 & 0.167 & 0.000 & 54.709 \\
\hline Canada & 382 & -0.000024400 & 0.047 & 0.076 & 0.035 & 1.079 & 1.720 & 0.436 & 0.113 & 56.565 \\
\hline Cayman Islands & 35 & -0.000006890 & 0.078 & 0.088 & 0.156 & 2.710 & 1.639 & 0.146 & 0.000 & 48.708 \\
\hline China & 96 & -0.000021500 & 0.053 & 0.086 & 0.099 & 0.728 & 1.290 & 0.751 & 0.000 & 52.200 \\
\hline Denmark & 126 & -0.000001850 & 0.109 & 0.096 & 0.164 & 3.031 & 1.480 & 0.221 & 1.000 & 55.689 \\
\hline Finland & 129 & -0.000020600 & 0.089 & 0.070 & 0.148 & 1.169 & 1.730 & 0.303 & 1.000 & 62.084 \\
\hline France & 536 & -0.000012200 & 0.066 & 0.071 & 0.099 & 1.245 & 1.233 & 0.175 & 0.979 & 62.655 \\
\hline Greece & 39 & -0.000018900 & 0.081 & 0.049 & 0.149 & 0.925 & 1.115 & 0.306 & 1.000 & 67.491 \\
\hline Hong Kong SAR. & 111 & -0.000004600 & 0.080 & 0.246 & 0.132 & 1.257 & 1.612 & 0.147 & 0.000 & 55.050 \\
\hline India & 113 & -0.000001450 & 0.114 & 1.981 & 0.168 & 2.154 & 1.413 & 0.361 & 0.000 & 62.934 \\
\hline Indonesia & 27 & 0.000017000 & 0.103 & 0.230 & 0.071 & 5.322 & 2.311 & 0.226 & 0.000 & 68.312 \\
\hline Ireland & 29 & -0.000023600 & 0.060 & 0.033 & 0.144 & 1.012 & 1.488 & 0.223 & 1.000 & 45.706 \\
\hline Israel & 38 & -0.000002440 & 0.058 & 0.037 & 0.141 & 2.517 & 1.309 & 0.313 & 0.000 & 50.908 \\
\hline Italy & 142 & -0.000024400 & 0.053 & 0.076 & 0.048 & 0.938 & 1.061 & 0.228 & 1.000 & 61.209 \\
\hline Japan & 1.775 & -0.000000002 & 0.046 & 0.037 & 0.058 & 0.609 & 1.722 & 0.285 & 0.682 & 54.056 \\
\hline Korea. Rep. & 113 & -0.000000001 & 0.054 & 0.112 & 0.075 & 0.733 & 1.327 & 0.380 & 0.619 & 57.758 \\
\hline Luxembourg & 27 & 0.000001980 & 0.078 & 0.091 & 0.161 & 2.205 & 1.197 & 0.272 & 1.000 & 62.559 \\
\hline Malaysia & 29 & -0.000010300 & 0.068 & 0.052 & 0.256 & 1.886 & 1.359 & 0.381 & 0.000 & 54.440 \\
\hline New Zealand & 57 & -0.000002170 & 0.099 & 0.104 & 0.148 & 1.396 & 1.193 & 0.278 & 0.982 & 48.311 \\
\hline Norway & 48 & -0.000004210 & 0.008 & -0.014 & 0.072 & 2.386 & 1.810 & 0.184 & 1.000 & 50.597 \\
\hline Philippines & 55 & 0.000000699 & 0.085 & 0.186 & 0.160 & 1.167 & 1.446 & 0.184 & 0.000 & 52.784 \\
\hline Poland & 23 & -0.000000777 & 0.064 & 0.065 & 0.068 & 0.558 & 1.663 & 0.475 & 1.000 & 51.462 \\
\hline Portugal & 46 & -0.000029000 & 0.063 & 0.185 & 0.299 & 1.187 & 1.059 & 0.220 & 1.000 & 63.934 \\
\hline Russian Federation & 28 & -0.000002480 & 0.149 & 0.257 & 0.283 & 1.209 & 1.943 & 0.809 & 0.000 & 37.793 \\
\hline Singapore & 56 & 0.000012400 & 0.052 & 0.148 & 0.094 & 0.837 & 1.415 & 0.147 & 0.196 & 52.497 \\
\hline South Africa & 350 & -0.000015100 & 0.073 & 0.089 & 0.105 & 1.863 & 1.637 & 0.849 & 0.140 & 53.638 \\
\hline Spain & 196 & -0.000012900 & 0.070 & 0.170 & 0.137 & 1.232 & 1.192 & 0.231 & 1.000 & 64.436 \\
\hline Sweden & 222 & -0.000000312 & 0.085 & 0.066 & 0.152 & 1.197 & 1.483 & 0.139 & 1.000 & 62.004 \\
\hline Switzerland & 256 & -0.000004030 & 0.096 & 0.098 & 0.157 & 1.893 & 1.796 & 0.109 & 0.875 & 60.238 \\
\hline $\begin{array}{l}\text { Thailand } \\
\text { The }\end{array}$ & 22 & -0.000009210 & 0.065 & 0.142 & 0.129 & 2.403 & 1.505 & 0.310 & 0.000 & 61.159 \\
\hline United Kingdom & 1570 & -0.000005110 & 0.076 & 0.063 & 0.163 & 1.377 & 1.388 & 0.235 & 0.989 & 51.122 \\
\hline United States & 1123 & -0.000006400 & 0.088 & 0.125 & 0.148 & 1.678 & 1.793 & 0.396 & 0.922 & 54.054 \\
\hline Total & 9175 & -0.000007250 & 0.067 & 0.099 & 0.108 & 1.302 & 1.551 & 0.313 & 0.755 & 55.602 \\
\hline
\end{tabular}

The descriptive statistics of mean values by country, with 9175 observations covering the 39 countries with more than 20 observations. 


\section{References}

1. Heal, G. Endangered Economies; Columbia University Press: New York, NY, USA, 2016.

2. Coward, H.; Hurka, T. Ethics and Climate Change: The Greenhouse Effect; Wilfrid Laurier University Press: Waterloo, ON, Canada, 2006

3. United Nations. Ahead of Climate Action Summit, UN Secretariat Adopts Plan to Slash Own Emissions by almost Half by 2030. (2019, September). Available online: https://www.un.org/sustainabledevelopment/blog/2019/09/un-secretariat-climateaction-plan/\#: \{\}:text=New\%20York \%2C\%2022\%20September $\% 20 \%$ E2\%80\%94\%20The,from $\% 20$ renewable $\% 20$ energy $\% 20$ by\%202030 (accessed on 12 July 2021).

4. European Commission. EU Climate Action and the European Green Deal. 2021. Available online: https://ec.europa.eu/clima/ policies/eu-climate-action_en (accessed on 12 July 2021).

5. Busch, T.; Bassen, A.; Lewandowski, S.; Sump, F. Corporate Carbon and Financial Performance Revisited. Organ. Environ. 2020, 5-18. [CrossRef]

6. Delmas, M.; Nairn-Birch, N.; Lim, J. Dynamics of environmental and financial performance: The case of greenhouse gas emissions. Organ. Environ. 2015, 28, 374-393. [CrossRef]

7. Lewandowski, S. Corporate Carbon and Financial Performance: The Role of Emission Reductions. Bus. Strat. Environ. 2017, 26, 1196-1211. [CrossRef]

8. Galama, J.T.; Scholtens, B. A meta-analysis of the relationship between companies' greenhouse gas emissions and financial performance. Environ. Res. Lett. 2021, 16, 043006. [CrossRef]

9. Fujii, H.; Iwata, K.; Kaneko, S.; Managi, S. Corporate Environmental and Economic Performance of Japanese Manufacturing Firms: Empirical Study for Sustainable Development. Bus. Strat. Environ. 2012, 22, 187-201. [CrossRef]

10. Fernández-Cuesta, C.; Castro, P.; Tascón, M.T.; Castaño, F.J. The effect of environmental performance on financial debt. European evidence. J. Clean. Prod. 2019, 207, 379-390. [CrossRef]

11. Gallego-Álvarez, I.; García-Sánchez, I.M.; Vieira, C.D.S. Climate Change and Financial Performance in Times of Crisis. Bus. Strat. Environ. 2014, 23, 361-374. [CrossRef]

12. Gallego-Álvarez, I.; Segura, L.; Martinez-Ferrero, J. Carbon emission reduction: The impact on the financial and operational performance of international companies. J. Clean. Prod. 2015, 103, 149-159. [CrossRef]

13. Iannotta, G.; Nocera, G.; Sironi, A. Ownership structure, risk and performance in the European banking industry. J. Bank. Financ. 2007, 31, 2127-2149. [CrossRef]

14. Busch, T.; Lewandowski, S. Corporate carbon and financial performance: A meta-analysis on corporate carbon and financial performance. J. Ind. Ecol. 2018, 22, 745-759. [CrossRef]

15. Kim, Y.; An, K.; Kim, J. The effect of carbon leverage on the cost of equity capital. J. Clean. Prod. 2015, 93, 279-287. [CrossRef]

16. Kor, Y.Y.; Mahoney, J.T. How dynamics, management, and governance of resource deployments influence firm-level performance. Strat. Manag. J. 2005, 26, 489-496. [CrossRef]

17. Alonso-Martínez, D.; De Marchi, V.; Di Maria, E. Which country characteristics support corporate social performance? Sustain. Dev. 2019, 28, 670-684. [CrossRef]

18. Jiménez-Parra, B.; Alonso-Martínez, D.; Godos-Díez, J.-L. The influence of corporate social responsibility on air pollution: Analysis of environmental regulation and eco-innovation effects. Corp. Soc. Responsib. Environ. Manag. 2018, 25, 1363-1375. [CrossRef]

19. Kolk, A.; Pinkse, J. Business Responses to Climate Change: Identifying Emergent Strategies. Calif. Manag. Rev. 2005, 47, 6-20. [CrossRef]

20. World Bank. Carbon Pricing Dashboard [Data File]. 2020. Available online: https:/ / carbonpricingdashboard.worldbank.org/ map_data (accessed on 12 July 2021).

21. Burney, N. Carbon Tax and Cap-and-Trade Tools: Market-Based Approaches for Controlling Greenhouse Gasses; Nova Science Publishers, Inc.: New York, NY, USA, 2010.

22. Brouwers, R.; Schoubben, F.; Van Hulle, C. The influence of carbon cost pass through on the link between carbon emission and corporate financial performance in the context of the European Union Emission Trading Scheme. Bus. Strat. Environ. 2018, 27, 1422-1436. [CrossRef]

23. Brouwers, R.; Schoubben, F.; Van Hulle, C.; Van Uytbergen, S. The initial impact of EU ETS verification events on stock prices. Energy Policy 2016, 94, 138-149. [CrossRef]

24. Griffin, P. Cap-and-trade emission allowances and US companies' balance sheets. Sustain. Account. Manag. Policy J. 2013, 4, 7-31. [CrossRef]

25. Marin, G.; Marino, M.; Pellegrin, C. The Impact of the European Emission Trading Scheme on Multiple Measures of Economic Performance. Environ. Resour. Econ. 2018, 71, 551-582. [CrossRef]

26. De Giovanni, P.; Vinzi, V.E. The benefits of the emissions trading mechanism for Italian firms: A multi-group analysis. Int. J. Phys. Distrib. Logist. Manag. 2014, 44, 305-324. [CrossRef]

27. Jong, T.; Couwenberg, O.; Woerdman, E. Does EU emissions trading bite? An event study. Energy Policy 2014, 69, 510-519. [CrossRef]

28. Luo, L.; Tang, Q. Carbon tax, corporate carbon profile and financial return. Pac. Account. Rev. 2014, 26, 351-373. [CrossRef] 
29. Sato, M.; Grubb, M.; Cust, J.; Chan, K.; Korppoo, A.; Ceppi, P. Differentiation and Dynamics of Competitiveness Impacts from the EU ETS; Working Paper; University of Cambridge: Cambridge, UK, 2007.

30. Russo, M.; Fouts, P. A resource-based perspective on corporate environmental performance and Profitability. Acad. Manag. J. 1997, 40, 534-559.

31. Beck, C.; Frost, G.; Jones, S. CSR disclosure and financial performance revisited: A cross-country analysis. Aust. J. Manag. 2018, 43, 517-537.

32. Sariannidis, N.; Zafeiriou, E.; Giannarakis, G.; Arabatzis, G. $\mathrm{CO}_{2}$ Emissions and Financial Performance of Socially Responsible Firms: An Empirical Survey. Bus. Strat. Environ. 2013, 22, 109-120. [CrossRef]

33. Reuters, T. Thomson Reuters Datastream Factsheet. 2018. Available online: https://www.eui.eu/Documents/Research/Library/ ResearchGuides/Economics/PDFs/Datastream-2019-Factsheet.pdf (accessed on 21 May 2021).

34. Busch, T.; Hoffman, V. How hot is your bottom Line? Linking carbon and financial performance. Bus. Soc. 2011, 50, 233-265. [CrossRef]

35. Durrah, O.; Rahman, A.; Jamil, S.; Ghafeer, N. Exploring the relation between liquidity ratios and indicators of financial performance: An analytical study on food industrial companies listed in Amman Bursa. Int. J. Econ. Financ. Issues 2016, 6, 435-441.

36. Chung, K.H.; Pruitt, S.W. A Simple Approximation of Tobin's q. Financ. Manag. 1994, 23, 70. [CrossRef] 